\title{
Differentiation and pricing power of online retailers
}

\author{
Zhenjie Wang, Chunling Zhu*, Shanwu Tian and Ping Li
}

\author{
* Correspondence: zhuchunling@ \\ rmbs.ruc.edu.cn \\ Business School, Renmin University \\ of China, Beijing 100872, China
}

\begin{abstract}
This study aims to contribute to marketing theory by applying monopolistic competition theory to investigate how differentiation affects online retailers' pricing power. We examine the intermediary effect of customer loyalty on the relationship between differentiation and pricing power of online retailers. We assume that customers have different preferences for the differentiated characteristics of online retailers, and thus different degrees of willingness to pay premiums, which gives online retailers pricing power. Structural equation modeling (SEM) is employed to test the hypothesized relationships between differentiation, customer loyalty, and pricing power. The statistical results of the empirical data indicate that some of the differentiation characteristics of online retailers can cultivate their pricing power indirectly. Logistics quality followed by commodity assortment and transaction security produces profound effects on the buildup of pricing power with customer loyalty as an intermediary factor. Results further reveal that commodity quality is positively related to pricing power. This study expands the definition of differentiation by combining corporate strategic positioning with commodity pricing. Implications for practice and directions for future research are provided.
\end{abstract}

Keywords: Online retailer, Differentiation, Pricing power, Customer loyalty, Logistics quality, Commodity assortment, Transaction security

\section{Introduction}

Online shopping has become increasingly popular as it brings convenience, saves search costs and reduces difficulties in choosing products (Wimble et al. 2016; Bakos 1997). The proliferation of shopping websites triggers ever increasing numbers of alternatives for online customers (Luo et al. 2012). This wide application of networks in shopping reduces the difficulty for customers to obtain market information (Chen et al. 2014), which weakens online retailers' pricing power.

However, we find that, in the majority of cases, the same goods are priced quite differently by different online retailers, and higher-priced online retailers do not necessarily sell fewer goods than lower-priced ones. This ability to set a higher price without significantly reducing sales is referred to as pricing power (Li et al. 2013). Most existing research on retailers' pricing has mainly focused on the cost advantage (Carlson and McAfee 1983), marketing strategy (Wildenbeest 2011) and retailers' characteristics (Luo et al. 2012; Zhuang et al. 2018), while paying little attention to factors from the perspective of differentiation.

(c) The Author(s). 2019 Open Access This article is distributed under the terms of the Creative Commons Attribution 4.0 International License (http://creativecommons.org/licenses/by/4.0/), which permits unrestricted use, distribution, and reproduction in any medium, provided you give appropriate credit to the original author(s) and the source, provide a link to the Creative Commons license, and indicate if changes were made. 
The pricing power of retailers is dependent on many factors, including the peculiarity of goods in the market, competition with similar goods, customers' perspectives on quality and effectiveness of commodities or firms' advertising ( $\mathrm{Li}$ et al. 2013). Retailers have gained pricing power in a number of ways (Richards and Pofahl 2010). First, they sell a variety of goods, which is convenient for customers. Second, they are spatially close to customers and allow people to save time while shopping, which also increases the convenience of shopping. Finally, retailers have increasingly differentiated themselves to attract customers with diversified demands.

We add to this line of research by introducing the differentiation competition theory to explore the impact of differentiation on pricing power. We re-clarify the differentiated characteristics of online retailers into the dimensions of commodities, security, and sales channels. Online retailers usually differentiate themselves in terms of market positioning, commodities and service characteristics to meet the diversified demands of customers. We believe that the commodity features, transaction security and online retailers' sales channels are linked to the pricing power of online retailers.

Customer loyalty is defined as a customer's deep commitment to the online retailer (Shankar et al. 2003), and as an approval of retailers that is expressed by continuing to buy from that retailer and/or recommending the retailer to others (Huang 2011), regardless of any influence from other competitors' marketing activities (Oliver 1997). Loyal customers intend to stay with the organization and they commit to increase the breadth and depth of products or services purchased in their relationship with these firms (Zeithaml et al. 1996). Basically, a customer is loyal when he/she is committed to repurchase a preferred service or product even when marketing efforts and situational influences have the potential to cause switching behavior (Oliver 1997). For retailers, loyal customers buy more, are willing to spend more, and act as enthusiastic advocates for their firms (Harris and Goode, 2004). For customers, loyalty is operationalized as the minimum price differential needed before consumers who prefer one retailer switch to another retailer (Raju et al. 1990). We believe the differentiated characteristics of online retailers can lead to customer loyalty, which is the source of their willingness to pay a premium (Zeithaml et al. 1996; Srinivasan et al. 2002).

In order to systematically and comprehensively capture the differentiation characteristics of online retailers and their impact on pricing power, we design a study to examine the influence of the sales channel, commodity and transaction security of online retailers on pricing power. We try to explore whether these differentiation characteristics can form pricing power and what are the functioning mechanisms of differentiation characteristics on online retailers' pricing power. We further investigate whether customer loyalty works as an intermediary variable between differentiation and pricing power. Thus, we propose a conceptual framework through which differentiating factors of online retailers affect their pricing power as illustrated in Fig. 1. In this conceptual model, differentiating features of online retailers are treated as the antecedent variables, pricing power as the outcome variable, and customer loyalty as the mediating variable.

By proposing this theoretical framework, this study contributes to literature development in the following three aspects. First, we expand the application of the traditional differentiation theory from the product level to the firm level by identifying three major characteristics that affect the pricing power of online retailers. This is consistent with the conclusion that differentiation can reduce competition and increase the market 


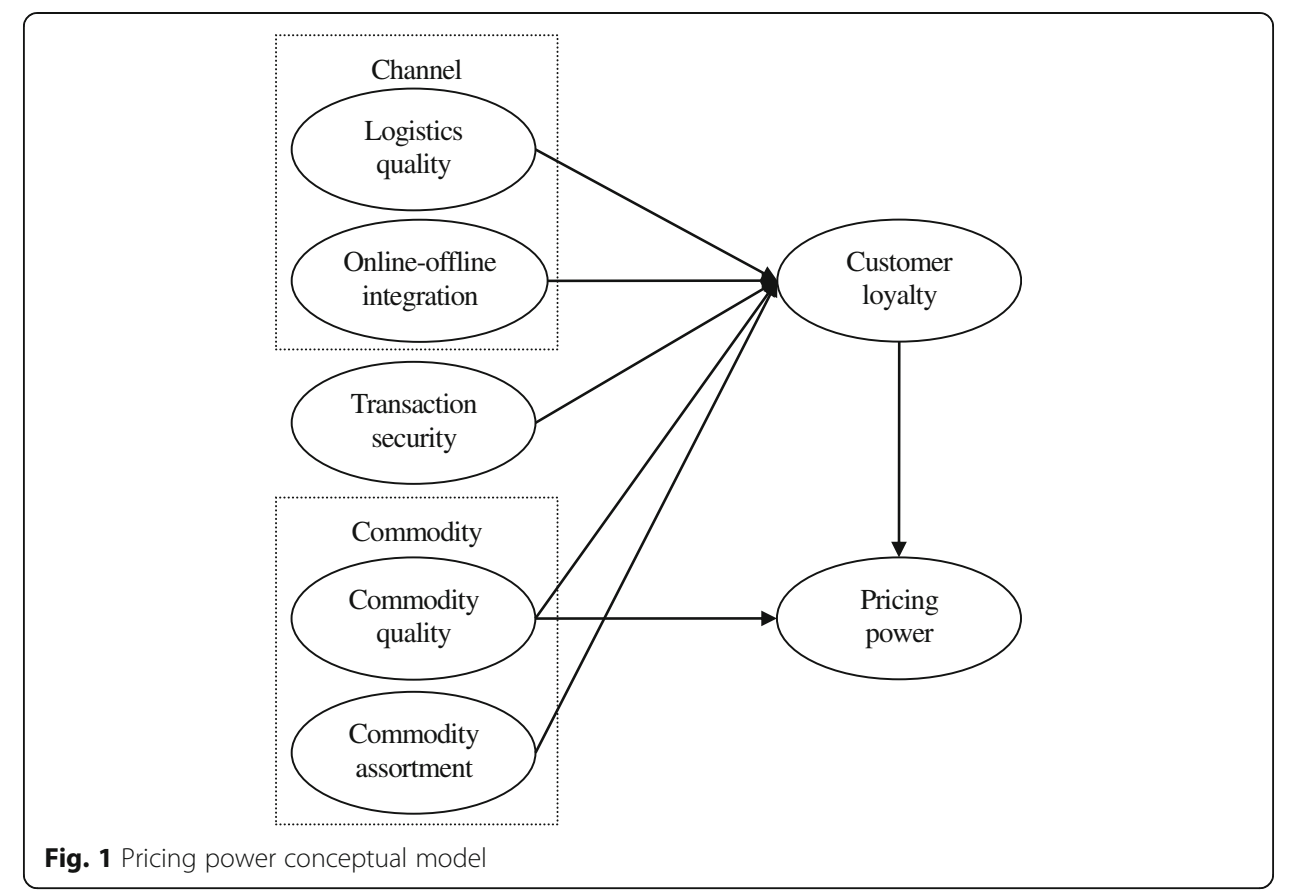

power of enterprises. Second, we emphasize the important role of customer choice and take customer loyalty as an intermediary variable to explore the key role of online retailers' differentiation in the formation of their pricing power. From a theoretical point of view, this analysis on the pricing power of online retailers is both a supplement to and validation of the theory of monopolistic competition in the context of the Internet economy. Third, in a practical sense, this research confirms the effectiveness of non-price competition tactics in allowing online retailers to profit from a price higher than the marginal cost. Under such circumstances, they can earn good profits while maintaining competitive advantage instead of sticking to a low price strategy.

In the following sections, we develop hypotheses (section 2) through briefly reviewing the literature on differentiation, pricing power, and customer loyalty. Then, the methodology for the study is introduced in section 3. We empirically analyze the data and draw conclusions in section 4. Implications and limitations are discussed in the last section.

\section{Theory and hypotheses development}

\section{Differentiation of online retailers}

The concept of differentiation originates at the product level, and refers to the same type of products with significant differences and no complete substitution relationship (Waldman and Jensen 2013). Through product differentiation, enterprises can increase the demand and reduce the price elasticity of demand to expand their profits (Waldman and Jensen 2013). Based on the theory of monopoly competition, a higher degree of product differentiation softens competition (Zhelobodko et al. 2012). Enterprises can develop pricing power because the differentiation characteristics of commodities can form their market power for pricing a small range of commodities. This difference is not necessarily the difference in terms of physical attributes between goods, but in terms of customers' perception of the difference in sales location, service quality and 
other subjective perceptions (Waldman and Jensen 2013). When customers get goods from a few online retailers with no difference, the differentiated traits of different online retailers can form varying degrees of attraction, thereby reducing customers' price sensitivity (Graciola et al. 2018).

The differentiation perceived by customers is shaped during the online purchase process (Lin and Sun 2009). Most studies on the differentiation characteristics of online retailers examine the commodity dimension, customer service and promotion dimension, website navigation and customer convenience dimension, and security dimension (Szymanski and Hise 2000; Liu and Arnett 2000; Park and Kim 2003; Davari et al. 2016). In terms of the commodity dimension, commodity assortment (Park and Kim 2003) and the quality of commodities (Chen et al. 2017b) are mainly considered. In terms of customer service and promotion, it mainly refers to the use of lower prices and better service to attract repeat customers (Kolesar and Galbraith 2000). In the dimension of website navigation and customer convenience, shopping website interface design (Chen et al. 2017a) and customer commodity search convenience (Rohm and Swaminathan 2004) are the main factors considered. The security dimension mainly considers customer privacy and protection of shopping information (Kukar-Kinney and Close 2010). In the convenience dimension, some studies consider the speed of logistics (Forsythe and Shi 2005).

Based on the existing classification methods, we reclassify the differentiated characteristics of online retailers into the dimensions of commodities, security, and sales channels. The dimensions of commodities mainly include the quality of goods and assortment of commodities. The security dimension mainly refers to the degree of transaction security, which includes the safety of customer property, and the information security of customers. The sales channel dimension mainly includes logistics quality and the degree of integration of online and offline channels.

\section{Differentiation of sales channel and customer loyalty}

As a link between online retailers and customers, the logistics system is an indispensable part of online shopping. The logistics quality of online retailers has a direct impact on buyers' enjoyment (Mentzer and Flint 2001) and perceived value (Zehir and Narcıkara 2016). Quality logistics has evolved into an important source of competitiveness (Mentzer and Flint 2001). Moreover, logistics service companies can attract customers and offer additional value to supplier companies (namely clients of logistics firms) by improving service performance (Novack et al. 1994). Especially in the online retail industry, the quality of logistics represents the convenience retailers provide to customers, and it is also a direct reflection of the service quality of retailers.

Some online retailers (JD, Vipshop, etc.) have developed their own logistics systems. Good logistics service quality can exceedingly enhance customer satisfaction, and help accumulate customer loyalty (Jang et al. 2013). High-efficiency logistics shorten the waiting time of customers; stable and secure logistics eliminate loss derived from damage to goods; home delivery services allow customers to avoid troublesome pick-up. Hence, it is safe to say higher logistics quality increases the loyalty of customers. Thus, we propose Hypothesis 1: 


\section{Hypothesis 1: Online retailers providing better logistics quality receive higher} customer loyalty.

Retail channel integration is defined as the degree to which different distribution channels interact with each other (Bendoly et al. 2005; Herhausen et al. 2015). From the perspective of online retailers, online-offline integration generally refers to when online retailers incorporate brick-and-mortar retailers into their channels to improve the efficiency of distribution (Herhausen et al. 2015). Some online retailers have already started to integrate their online and offline channels (Gallino and Moreno 2012). Online ordering with in-store pick-up and payment, purchases made in store with delivery through online channels, and offline fitting rooms, etc. have gradually been realized (Steinfield et al. 2002).

Many consumers enjoy trying products in stores and buying online (Zhang et al. 2010). The "order online and pick-up at store" mode can not only decrease the odds that customers are not satisfied with goods purchased by providing actual access to products before ordering, but also to some degree reduces the waiting time for delivery (Knop et al. 2016). Furthermore, the "order at store and delivery through online channels" mode provides customers with direct perceptions of commodity quality. Meanwhile the online supply channel enables home delivery and thus avoids self-pickup costs.

Lee and Kim (2010) point out that online-offline integration contributes to increasing customer loyalty, as well as stimulating online purchase intentions, reducing cost and strengthening enterprise differentiation. In addition to this, it can also stimulate customer loyalty by offering value-added services (Gallino and Moreno 2012). Thus, we come to Hypothesis 2.

Hypothesis 2: By integrating online and offline channels, online retailers can receive higher customer loyalty.

\section{Transaction security and customer loyalty}

As online shopping becomes more frequent, personal information leakage incidents have been increasing. How to protect the information security of customers has become an urgent issue for online retailers. Thus, the security of online trading is the basis of customer trust (Peštek et al. 2011). The transaction security includes payment security and information security. Hong and Cha (2013) find that online payment risks have tremendous negative impacts on purchase intentions. Consumer perceptions of financial security plays an important role in e-loyalty (Szymanski and Hise 2000). For the sake of property security, customers are more likely to prefer a relatively safe online retailer.

As well, online interactions involve communication and storage of information. Therefore, transaction security requires online retailers to safeguard information given to them and to protect information during communication (Madu and Madu 2002). Intyaswati and Komunikasi-Upn (2017) find that transaction information security and consumer privacy each affects brand loyalty. Accordingly, good protection for customers' property and privacy is of great significance for customer purchase intentions and loyalty. 
Hypothesis 3: Online retailers with higher transaction security receive higher customer loyalty.

\section{Differentiation of commodities and customer loyalty}

Existing literature on the characteristics of the product commonly uses the dimensions of product assortment and product quality (Davari et al., 2016). Commodity quality is a characteristic of goods that bear the ability to satisfy customer needs (Kotler and Armstrong 2010). For a tangible commodity, quality includes features, usability, or compatibility (Reich et al. 2006). Champion et al. (2010) find that the higher the quality is, the higher the willingness to buy. From the view of repeated game theory, a purchase experience of a lower quality commodity will reduce the customer's desire to buy again, while high quality of goods can attract repeat customers (Mailath and Samuelson 2014).

A series of studies has shown that product quality has a remarkable positive effect on customer loyalty (Yuen and Chan 2010; Reich et al. 2006; Sarv et al., 2001). In most cases, customers have no way to check commodity quality before online shopping, and thus the comparison between the commodity description and the received commodity is the direct source of customer-perceived quality. If the commodity received is not consistent with the description online, it will be difficult to gain loyalty from customers. Consequently, we make the following hypothesis.

Hypothesis 4: Online retailers providing commodities with higher consistency between commodity description and actual quality receive higher customer loyalty.

Previous studies have found that higher commodity assortment increases the probability that customer needs will be met (Bhatnagar and Syam 2014; Park and Kim 2003; Davari et al. 2016). An online retailer offering greater variety in commodity categories can improve shopping convenience (Dellaert et al. 1998) by reducing the hassle of cross-retailer purchasing, especially for those consumers who need to buy commodities with high search costs, or to purchase multiple types of commodities in one trip.

A greater variety of commodities not only attracts customers' patronage (Ganesh et al. 2010), but also enhances their perceptions of service quality by providing them with more choices that can meet their requirements (Davari et al. 2016). The breadth (number of brands) and depth (number of specifications) of an assortment offered in an online retailer helps it cater to the composite demands of their customers (Dhar et al. 2001). Therefore, whether from the perspective of customer demand or convenience, higher commodity assortment can produce repeated purchase intentions and loyalty from consumers. Accordingly, we propose the following hypothesis.

Hypothesis 5: Online retailers with greater commodity assortment receive higher customer loyalty.

\section{Commodity quality and pricing power}

From the perspective of indirect influence, Hypothesis 4 notes that commodity quality can increase the pricing power of online retailers by improving customer loyalty. 
Considering that the cost of goods with higher quality is higher than that of fake and inferior products, it is impossible to compete with them on price. Usually, goods of higher quality tend to be priced higher (Shapiro 1983; Kirmani and Rao 2000; Whitefield and Duffy 2012). In addition, the quality of goods consistent with the online description is the premise of consumers' trust (Konuk 2018; Caceres and Paparoidamis 2007) and repeat purchases (Ayadi et al. 2013). These are the foundation of pricing power (Jarmon 2009). Based on the cost perspective and continuous purchase, we propose the following hypothesis.

\section{Hypothesis 6: Commodity quality is directly linked to pricing power.}

\section{Customer loyalty and pricing power}

Marketing studies conceptualize loyalty as a behavioral response expressed over time, and gauge it through metrics such as proportion of purchase, purchase sequence, and purchase frequency (Brody and Cunningham, 1968; Raju et al. 1990; Christodoulides and Michaelidou 2011). It often appears as a result variable of consumer convenience, satisfaction and other perception factors in some studies (Pattanayak et al. 2017; Ngo and Pavelková 2017; Christodoulides and Michaelidou 2011). Therefore, customer loyalty can be regarded as a direct inducement of purchase intention and behavior.

Reichheld and Sasser (1990) find that customers with high customer loyalty tend to praise the brand and recommend it to others. When customers praise retailers, or show a preference for them, they increase purchases or gladly pay a premium (Zeithaml et al. 1996). Other studies have found that customers with high loyalty have low price flexibility and are willing to pay a premium to keep trading with their preferred retailers (Reichheld and Sasser 1990; Srinivasan et al. 2002) and focus on the economic and transaction relationship, while those with low loyalty only focus on the economic aspect (Jain et al., 1987). This suggests that customers with high loyalty levels have lower price flexibility (Reichheld and Sasser 1990), which is an important source of extra profit for online retailers.

The pricing power of suppliers as well as the source of pricing power have long been the subject of research, from both quantitative and qualitative points of view (Berenson et al. 2012; Robinson 2011; Vogt et al., 2006). As for the source of pricing power, extant research mainly focuses on the cost advantage (Carlson and McAfee 1983), marketing strategy (Wildenbeest 2011) and retailers' characteristics (Luo et al. 2012; Zhuang et al. 2018). Li et al. (2013) hold the view that the pricing power of enterprises is dependent on the peculiarity of goods in the market, competition with similar goods, customers' perspectives on quality and effectiveness of commodities or firms' advertising. Under a correct strategy, good reputation can provide certain positive effects upon retailers' pricing power (Jarmon 2009). From the above analysis, we come to the conclusion that retailers can gain pricing power from several sources, ultimately by increasing customer loyalty and, in turn, stimulating their willingness to pay a premium (Richards and Pofahl 2010). Therefore, we make the following assumption.

Hypothesis 7: Higher customer loyalty is positively related to online retailers' pricing power. 
We propose that differentiation of sales channels is positively related to customer loyalty (Hypotheses 1 and 2). We also argue that both transaction security and differentiation of commodities positively affect customer loyalty (Hypotheses 3, 4 and 5). We anticipate that customer loyalty is positively linked to online retailers' pricing power. All these hypotheses are presented separately and are based on the structural equation model. To integrate these relationships, we propose a mediated model in which the differentiation characteristics of online retailers positively affect pricing power through the intermediary effect of customer loyalty. Thus, we propose the following hypothesis.

\section{Hypothesis 8: The differentiation of online retailers has a positive effect on pricing} power with customer loyalty as an intermediary.

\section{Methods}

\section{Sample and data collection}

The data used in this paper are obtained through surveying online customers from November to December 2017. Respondents were recruited online and each paid two yuan for providing answers to the questionnaire based on their recent personal online shopping experiences. The first section of the questionnaire evaluates the demographic information of respondents. The second section of the questionnaire contains items to measure differentiating features of online retailers, customer loyalty, and respondents' willingness to pay premium prices.

The questionnaire was edited on wjx.cn and distributed through WeChat. Respondents answered questions either via WeChat or computer webpages, with no difference in the questionnaire content, but only in the operation terminal. The respondents who answered the questionnaire are either from our own WeChat contacts or from our friends' WeChat contacts, and have a wide range of educational and professional backgrounds. Since the questionnaire was shared through a double-blinded process, the respondents are anonymous. Of the 408 questionnaires collected, only 3 responses were submitted through the computer terminals and 405 were answered through WeChat. To minimize the instability of results from random answers, 314 copies were identified as effective, by eliminating those consuming notably less time, on the basis of observation and comparison of time spent by each respondent in finishing the survey.

Descriptive statistics of the respondents are shown in Table 1. As we can see in the table, young people under 35 are the majority of respondents, similar to the age structure of online shopping groups. Respondents who have no online shopping experiences were excluded before the calculation, so the final effective responses total 314, with most shopping online more than once a month. The effective response rate is $76.96 \%$.

\section{Variable measures}

7 latent variables are involved, among which logistics quality, online-offline integration, commodity quality, commodity assortment and transaction security represent the differentiating features of online retailers; loyalty of customers is the mediating variable; and pricing power of online retailers is defined as the outcome variable. To ensure the reliability and validity of measured variables, we adopt the scales that have been widely cited in recent studies. 
Table 1 Respondents' profile description

\begin{tabular}{llll}
\hline & Item & Frequency & $\%$ \\
\hline Gender & Female & 164 & 52.2 \\
Age & Male & 150 & 47.8 \\
& $\leq 18$ & 1 & 0.3 \\
& $19-35$ & 228 & 72.6 \\
& $36-55$ & 75 & 23.9 \\
Education & $\geq 56$ & 10 & 3.2 \\
& High school and below & 67 & 21.3 \\
& Bachelor degree & 115 & 36.6 \\
Occupation & Graduate degree & 132 & 42.0 \\
& Civil servants & 53 & 16.9 \\
& Enterprise staff & 193 & 61.5 \\
Online shopping frequency & Students & 57 & 18.2 \\
(per month) & Others & 11 & 3.5 \\
& $\geq 4$ & 124 & 39.5 \\
& $1-3$ & 139 & 44.3 \\
& $\leq 1$ & 51 & 16.2 \\
& Never & 0 & 0 \\
\hline
\end{tabular}

Notes. $n=314$

\section{Logistics quality}

The measurement of the logistics quality of online retailers is mostly based on availability, timeliness, and reliability (including privacy protection) (Zehir and Narcıkara 2016; Huang et al. 2009; Maltz and Maltz 1998). As privacy protection has been included in the transaction security dimension, the scale here mainly includes timeliness and availability. We developed the scale based on Zehir and Narcikara (2016), and the new scale consists of three items, including: "This online retailer handles orders quickly," "You can check the progress of goods logistics accurately here," "The goods can reach you as soon as possible."

\section{Online-offline integration}

As a relatively new approach to channel integration, online-offline integration is becoming a theme of the new retail format. There is no ready scale to measure online-offline integration. Based on the current degree of integration, we developed a scale of online-offline integration. We interviewed six online shoppers and recorded their perception of the characteristics of the online-offline integration of online retailers. Then we identified and coded the key items and summarized them into entries. We invited experts and professionals in online business to vote for the best items to describe the characteristics of online-offline integration. Finally, three items emerged as the testing items: "This online store has offline experience stores," "It sells the same goods both online and offline," "You can place orders online and pick up goods offline."

\section{Commodity quality}

Garvin (1987) and Wachyudi (2017) propose a definition of product quality with 8 attributes: performance, features, conformance, reliability, durability, serviceability, aesthetics 
and customer-perceived quality (Yuen and Chan 2010). Consumers buy and trust commodities from online retailers based on online descriptions. Product quality can be measured through consumer perception on how far the characteristics of the perceived product quality is from the online description. We adopt the scale developed by Davari et al. (2016), which consists of three items, including: "This online store offers quality goods," "This online store offers reliable goods," "This online store offers goods that last."

\section{Commodity assortment}

This is defined as the number of different items in a merchandise category (Pan and Zinkhan 2006). We adopt the scale developed by Davari et al. (2016), which consists of three items, including: "The online store has a wide variety of products to choose from," "Current fashions and new products are easily available at this online store," "The online store stocks 'brand name' merchandise."

\section{Transaction security}

In the existing literature, the description of online transaction security is mostly based on property (Hong and Cha 2013; Szymanski and Hise 2000) and information security (Intyaswati and Komunikasi-Upn 2017). We adopt the scale developed by Park and Kim (2003), which consists of three items, including: "My private information is managed securely on this site," "I am sure that payment information will be protected in this site," and "This site provides detailed information about security."

\section{Customer loyalty}

This includes both attitudinal and behavioral practices, such as repeat buying of some products, ongoing shopping in one store, and insensitivity to price increases (Yuen and Chan 2010; Wangenheim and Bayon 2004; Lewis and Soureli 2006). We adopt the scale developed by Zeithaml et al. (1996) and Srinivasan et al. (2002), which consists of three items, including: "When I need to make a purchase, this online retailer is my first choice," "To me this online retailer website is the best retail website to do business with," "I will recommend this online retailer to my friends."

\section{Pricing power}

This refers to a retailer's ability to gain a higher than average premium compared to other competing retailers (Jarmon 2009). In industrial organization analysis methods, the Lena index ${ }^{1}$ is generally used as a measure of enterprise pricing power. However, the reality is that online retailers sell a wide range of commodities and have different levels of bargaining power, which makes the marginal cost of the industry almost impossible to obtain. In previous studies, most of them are expressed as willingness to pay more. We adopt the scale developed by Zeithaml et al. (1996) and Srinivasan et al. (2002), which consists of 3 items: "Will you continue to do business with this website if its prices increase somewhat?" "Will you stop doing business with this website if its competitors' prices decrease somewhat? (reverse coded)" "Will you pay a higher price at this website relative to the competitors for the same benefit?" 


\section{Reliability statistics}

In order to determine the validity of the goodness-of-fit evaluation and hypothesis testing of the model, it is necessary to carry out a reliability test on the collected questionnaire data. The Cronbach's Alpha, of which values exceeding 0.7 are generally regarded as implications of high reliability, is used in this paper to evaluate the survey. As is shown in Table 2, all the Cronbach's Alpha statistics of latent variables surpass 0.7, and the overall reliability is 0.929 . This indicates that the questionnaire has excellent reliability.

\section{Exploratory factor analysis (EFA)}

In the study, all indicators are measured simultaneously, and then put through factor analyses. Then the factor loading value is used to determine the construct validity. Higher factor loading values in one dimension with lower ones in others indicate clear internal structures of the survey and high overall construct validity. We carried out the EFA on the raw questionnaire data with the help of SPSS 21.0 so as to preliminarily check the convergent and discriminant validity. The Kaiser-Meyer-Olkin (KMO) measure equals to 0.900 , showing that the data are suitable for factor analyses. Barlett's test of sphericity gives an approximate Chi-square of 4,952.137 and significance at 0.000, indicating that variables are correlated with each other and factor analyses are applicable.

Twenty-one latent variables are attributed to seven principal components, which results in total variance explained reaching $82.052 \%$. The un-rotated factor loading matrix fails to reveal the meaning of each factor, and thus this paper manages to calculate the rotated component matrix by means of orthogonal rotation following the Kaiser normalization. Table 2 shows that all of the factor loads are higher than 0.6 (Bagozzi and Yi 1988). The classification of each measured variable is consistent with the expectation, so it is safe to say that the scale possesses a high overall validity.

We took some measures to minimize and test the effects of common method variance (CMV) (Li, 2014). First, we counterbalanced the survey question order. Then, we performed Harman's single-factor test based on an un-rotated exploratory factor analysis. The results show a 7 -factor structure with the largest factor explaining $42.5 \%$ of the variances, less than the threshold of 50\% (Podsakoff et al. 2003). The results suggest that CMV did not pose a serious problem in this study.

\section{Confirmatory factor analysis (CFA)}

AMOS 21.0 was used to analyze the data with the maximum likelihood estimation. The results show that no negative variance is seen in the output, and all of the standardized path coefficients lie between 0 and 1 , with no dramatic deviation. The standardized correlation coefficient between measured indicator and latent variable ranges from 0.768 to 0.977 , as is shown in Fig. 2, and all $p$ values are below 0.01 , which demonstrates that the measured variables can effectively reflect the latent variables behind them. $R^{2}$ is the multiple correlation coefficient in the structural equation model, which indicates the explanation degree of all variables. The $R^{2}$ of the explained variable customer loyalty and the pricing power of online retailers are 0.630 and 0.307 , respectively, within the acceptable range. 
Table 2 Results of reliability analysis

\begin{tabular}{|c|c|c|c|}
\hline Variable & $\begin{array}{l}\text { Factor } \\
\text { Loading }\end{array}$ & $\begin{array}{l}\text { Cronbach's } \\
\text { Alpha }\end{array}$ & Reference \\
\hline Logistics quality (LQ) & & \multirow[t]{4}{*}{0.834} & \multirow{4}{*}{$\begin{array}{l}\text { Zehir and } \\
\text { Narcıkara (2016) }\end{array}$} \\
\hline This online retailer handles orders quickly (a1) & 0.691 & & \\
\hline You can check the progress of goods logistics accurately here (a2) & 0.826 & & \\
\hline The goods can reach you as soon as possible (a3) & 0.762 & & \\
\hline Online-offline integration $(O /)$ & & \multirow[t]{4}{*}{0.891} & \multirow[t]{4}{*}{ This research } \\
\hline It has an offline experience store (a4) & 0.856 & & \\
\hline It sells goods both online and offline (a5) & 0.884 & & \\
\hline You can place orders online and pick up goods offline (a6) & 0.841 & & \\
\hline Transaction security (TS) & & \multirow[t]{4}{*}{0.913} & \multirow{4}{*}{$\begin{array}{l}\text { Park and Kim } \\
\text { (2003) }\end{array}$} \\
\hline My private information is managed securely on this site (a7) & 0.872 & & \\
\hline $\begin{array}{l}\text { I am sure that payment information will be protected in this site } \\
\text { (a8) }\end{array}$ & 0.847 & & \\
\hline This site provides detailed information about security (a9) & 0.841 & & \\
\hline Commodity quality $(C Q)$ & & \multirow[t]{4}{*}{0.897} & \multirow{4}{*}{$\begin{array}{l}\text { Davari et al. } \\
\text { (2016) }\end{array}$} \\
\hline This online store offers quality goods (a10) & 0.781 & & \\
\hline This online store offers reliable goods (a11) & 0.804 & & \\
\hline This online store offers goods that lasts (a12) & 0.720 & & \\
\hline Commodity assortment (CA) & & \multirow[t]{4}{*}{0.823} & \multirow{4}{*}{$\begin{array}{l}\text { Davari et al. } \\
(2016)\end{array}$} \\
\hline $\begin{array}{l}\text { The online store has a wide variety of products to choose from } \\
\text { (a13) }\end{array}$ & 0.796 & & \\
\hline $\begin{array}{l}\text { Current fashions and new products are easily available at this online } \\
\text { store (a14) }\end{array}$ & 0.778 & & \\
\hline The online store stocks "brand name" merchandise (a15) & 0.793 & & \\
\hline Customer loyalty $(C L)$ & & \multirow[t]{4}{*}{0.880} & \multirow{4}{*}{$\begin{array}{l}\text { Zeithaml et al. } \\
\text { (1996) } \\
\text { Srinivasan et al. } \\
\text { (2002) }\end{array}$} \\
\hline $\begin{array}{l}\text { When I need to make a purchase, this online retailor is my first } \\
\text { choice (a16) }\end{array}$ & 0.710 & & \\
\hline $\begin{array}{l}\text { To me this online retailor website is the best retail website to do } \\
\text { business with (a17) }\end{array}$ & 0.775 & & \\
\hline I will recommend this online retailor to my friends (a18) & 0.781 & & \\
\hline Pricing power $(P P)$ & & \multirow[t]{4}{*}{0.935} & \multirow{4}{*}{$\begin{array}{l}\text { Zeithaml et al. } \\
\text { (1996) } \\
\text { Srinivasan et al. } \\
\text { (2002) }\end{array}$} \\
\hline $\begin{array}{l}\text { Will you continue to do business with this website if its prices } \\
\text { increase somewhat (a19) }\end{array}$ & 0.796 & & \\
\hline $\begin{array}{l}\text { Will you stop doing business with this website if its competitors' } \\
\text { prices decrease somewhat (a20) }\end{array}$ & 0.898 & & \\
\hline $\begin{array}{l}\text { Will you pay a higher price at this website relative to the } \\
\text { competition for the same benefit (a21) }\end{array}$ & 0.915 & & \\
\hline
\end{tabular}

The overall fit index of the model is summarized in Table 3. The model fitting index is a statistical index to investigate the degree of data fitting of the theoretical structural model. In terms of absolute indices, the Chi-square $=297.125$, the degree of freedom $=$ 170 , and $p=0.000$, indicating that the Chi-square test results reach a statistically significant level. RMSEA $=0.049<0.05$; GFI $=0.921>0.9$; SRMR $=0.053<0.08$. The above absolute fit indices suggest that the model is acceptable. From perspectives of relative fit indices, $\mathrm{NFI}=0.942>0.9 ; \mathrm{TLI}=0.968>0.9 ; \mathrm{CFI}=0.974>0.9$; $\mathrm{IFI}=0.974>0.9$. They are all above 0.9 and close to 1 , which also demonstrates that the model is acceptable. As for the information coefficient, the ratio of Chi-square to the degree of freedom 


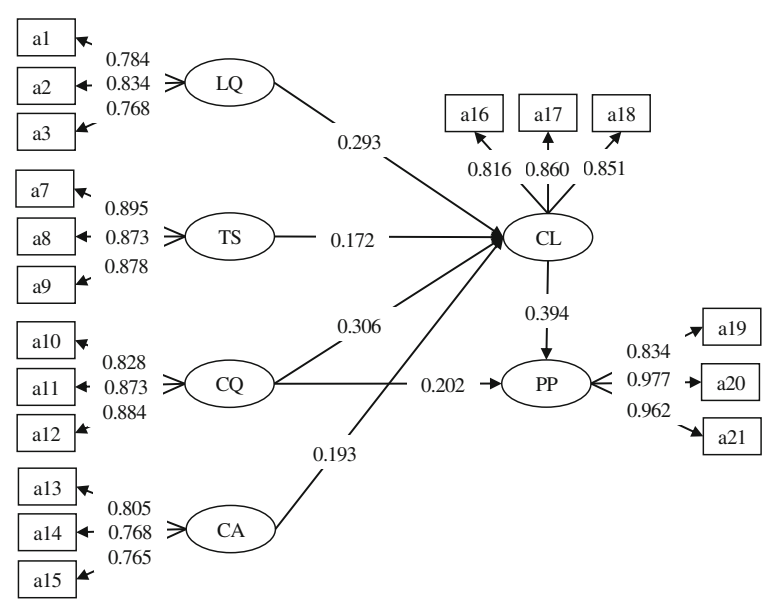

Fig. 2 Path model results. Notes: $L Q$ logistics quality, TS transaction security, CQ commodity quality, CA commodity assortment, CL customer loyalty, PP pricing power

$\mathrm{CMIN} / \mathrm{DF}=1.748<3$, suggesting that the model is acceptable. AIC $=419.125$, lower than 462.000 of the saturated model; PNFI $=0.762>0.5$; PGFI $=0.678>0.5$. These information coefficients all confirm that the model fulfills the requirements for parsimony fitting.

\section{Results}

Path analysis is a complex model composed of a series of mediating effects, which is the core of the path relation, and the element of the serial mediation relation is the common variable structure (Mackinnon, 2011). Meanwhile, the structural equation model can calculate the relationship between multiple dependent variables simultaneously, especially the intermediate effect (Lau and Cheung 2012). In order to test the hypothesized relationships between differentiation, customer loyalty, and pricing power, structural equation modeling (SEM) is employed. SEM is capable of dealing with

Table 3 Overall fitting indices

\begin{tabular}{|c|c|c|c|c|}
\hline & Fitting indice & Calculation & Reference & Evaluation \\
\hline \multirow[t]{4}{*}{ Absolute fit indices } & Chi-square & 297.125 & $\begin{array}{l}\text { As small as } \\
\text { possible }\end{array}$ & Accepted \\
\hline & $\begin{array}{l}\text { Root mean square error of approximation } \\
\text { (RMSEA) }\end{array}$ & 0.049 & $<0.05$ & Accepted \\
\hline & Goodness of fit index (GFI) & 0.921 & $>0.9$ & Accepted \\
\hline & Standardized RMR (SRMR) & 0.053 & $<0.08$ & Accepted \\
\hline \multirow[t]{3}{*}{ Relative fit indices } & $\begin{array}{l}\text { Normed fit index (NFI) } \\
\text { Tucker-Lewis index (TLI) }\end{array}$ & $\begin{array}{l}0.942 \\
0.968\end{array}$ & $\begin{array}{l}>0.9 \\
>0.9\end{array}$ & Accepted \\
\hline & Comparative fit index (CFI) & 0.974 & $>0.9$ & Accepted \\
\hline & Incremental fit index (IFI) & 0.974 & $>0.9$ & Accepted \\
\hline \multirow[t]{4}{*}{$\begin{array}{l}\text { Information } \\
\text { coefficients }\end{array}$} & $\begin{array}{l}\text { Chi-square divided by degrees of freedom } \\
\text { (CMIN/DF) }\end{array}$ & 1.748 & $<3$ & Accepted \\
\hline & Akaike information criterion (AIC) & 419.125 & $\begin{array}{l}<\text { saturated } \\
\text { models }\end{array}$ & Accepted \\
\hline & Parsimony normed fit index (PNFI) & 0.762 & $>0.5$ & Accepted \\
\hline & Parsimony goodness of fit index (PGFI) & 0.678 & $>0.5$ & Accepted \\
\hline
\end{tabular}


theoretical constructs which are measured by latent factors, and is a more powerful alternative to multiple regression for examining the complex interrelationships between constructs (Ngo and Pavelková 2017).

In path analysis, a structural equation can give a complex problem the most appropriate analysis. Much existing literature shows that it is unnecessary to combine other methods to further examine the mediating effect verified by SEM program (Christodoulides and Michaelidou 2010; Čater and Čater 2010; Husain 2017; Ribbink et al., 2004). Thus, we use the structural equation model to test all hypotheses. The results are displayed in Table 4.

Table 4 indicates that the path coefficient between logistics quality and customer loyalty is 0.293 , which means that logistics quality has a significant positive effect on customer loyalty. Thus, Hypothesis 1 is supported. Online-offline integration has no effect on customer loyalty. So Hypothesis 2 is rejected. The reason for this may be that channel convergence is not widespread enough for all respondents to experience the convenience of online and offline integration. The second possibility is that although the trend of channel integration is beginning to emerge, it is far from perfect, so the customer experience is not very significant. The standardized path coefficient between transaction security and customer loyalty is 0.172 , which means that transaction security is important for shopping on the net, and that customers are more loyal to a secure site. Thus, Hypothesis 3 is supported.

The standardized path coefficient between product quality and customer loyalty is 0.306 , which indicates the positive impact of product quality on customer loyalty. Hypothesis 4 is supported. The higher the product quality is, the higher customer loyalty is. Online retailers can gain customer recognition by improving the quality of products, so as to improve customer loyalty. The standardized path coefficient between product assortment and customer loyalty is 0.193 , which supports Hypothesis 5. A complete catalogue can reduce the nuisance of buying goods across stores, and a variety of goods that can be found in one place can reduce search costs.

The standardized path coefficient between product quality and pricing power is 0.202 , supporting Hypothesis 6 . This implies that it is possible to obtain consumer recognition through higher product quality. The standardized path coefficient between customer loyalty and pricing power is 0.394, which supports Hypothesis 7. Thus, we conclude that loyal customers are willing to pay a premium, underscoring the premium pricing power of online retailers.

Table 4 Analysis results

\begin{tabular}{|c|c|c|c|}
\hline Causal relation & $\begin{array}{l}\text { Standardized } \\
\text { path coefficient }\end{array}$ & C.R. ( $t$ value) & $p$ \\
\hline Customer loyalty <---logistics quality & 0.293 & 3.267 & *** \\
\hline Customer loyalty <---online-offline integration & 0.007 & 0.133 & 0.894 \\
\hline Customer loyalty <--- transaction security & 0.172 & 2.855 & $* * *$ \\
\hline Customer loyalty <---commodity quality & 0.306 & 3.642 & $* * *$ \\
\hline Customer loyalty <---commodity assortment & 0.193 & 2.548 & $* *$ \\
\hline Pricing power <--- commodity quality & 0.202 & 2.560 & ** \\
\hline Pricing power <---customer loyalty & 0.394 & 4.885 & $* * *$ \\
\hline
\end{tabular}

Notes. $n=314 ;{ }^{* * *} p<0.01,{ }^{* *} p<0.05$ 
We use SEM to calculate the intermediating effect between multiple dependent variables and pricing power simultaneously. All significantly correlated paths are depicted in Fig. 2. On the basis of the calculated path coefficients, direct, indirect and total effects between latent variables are obtained. Standardized path coefficients are illustrated in Table 5.

From Fig. 2 and Table 5, we can see that product quality has the largest direct and indirect effect on pricing power, with a total path coefficient of 0.323 . This shows that customers who want to buy higher quality goods are willing to pay a premium. Quality of logistics has an impact on pricing power with a total impact coefficient of 0.115 , which implies that online shoppers, driven by desirable logistics speed and safety, are often willing to pay premiums. Product assortment and transaction security possess relatively lower influences on pricing power, with total path coefficients of 0.076 and 0.068 respectively. However, online-offline integration of online retailers has no influences on pricing power. As the online-offline integration of online retailers has no influence on customer loyalty, the indirect influence of online-offline integration on pricing power has not been supported. Thus, Hypothesis 8 is also verified.

\section{Discussion}

\section{Conclusions}

From the perspective of information symmetry, the rise of online retail has reduced the pricing power of online retailers. However, based on monopolistic competition theory, online retailers using differentiated competition methods have more pricing power than other retailers. This can be seen by the price difference of homogeneous goods between

Table 5 Direct, indirect, and total effects between latent variables

\begin{tabular}{lll}
\hline & Customer loyalty & Pricing power \\
\hline Logistics quality & 0.293 & 0 \\
(Indirect effects) & 0 & 0.115 \\
(Total effects) & 0.293 & 0.115 \\
Online-offline integration & 0 & 0 \\
(Indirect effects) & 0 & 0 \\
(Total effects) & 0 & 0 \\
Transaction security & 0.172 & 0 \\
(Indirect effects) & 0 & 0.068 \\
(Total effects) & 0.172 & 0.068 \\
Commodity quality & 0.306 & 0.202 \\
(Indirect effects) & 0 & 0.121 \\
(Total effects) & 0.306 & 0.323 \\
Commodity assortment & 0.193 & 0 \\
(Indirect effects) & 0 & 0.076 \\
(Total effects) & 0.193 & 0.076 \\
Customer loyalty & - & 0.394 \\
(Indirect effects) & - & 0 \\
(Total effects) & - & 0.394 \\
\hline
\end{tabular}

Notes. All data shown in this table have been standardized. $n=314$ 
different online retailers. We assume that the price difference in question is, to some degree, attributed to the diverse pricing power of online retailers, and examine whether the competition strategy based on differentiation can be the source of pricing power, from the perspective of customer perceptions. We have two findings.

First, the differentiation strategy of online retailers can form their pricing power. Commodity differentiation (total effect: 0.399 ) and transaction security (total effect: 0.068) is beneficial to the pricing power of online retailers; channel differentiation focusing on improving logistics quality (total effect: 0.115 ) is also conducive to the formation of online retailers' pricing power. If online retailers adopt different aspects of differentiation, it will improve their competitiveness and pricing ability to varying degrees.

Second, the integration of online and offline channels has no influence on the pricing power of online retailers. It may be that the current level of integration is not high enough and the scope of integration is not widespread, so that customers do not have a clear distinction and perception of this differentiation characteristic.

\section{Theoretical contributions}

This research contributes to theoretical developments in the following ways. First, based on research into online retailer differentiation (Zhuang et al. 2018; Yun 2015), the differentiation characteristics of online retailers are systematically classified. Previous studies have not summarized the differentiation characteristics of online retailers, and the classification of the differentiation characteristics of online retailers has not been distinguished from that of brick-and-mortar retailers.

Second, previous studies have paid less attention to the influence of differentiation on the pricing power of online retailers. This study promotes the differentiation theory from the product level to the enterprise (online store) level, and summarizes the differentiation characteristics of online retailers into 5 types, which provides a new theoretical perspective for the marketing strategies of online retailers.

Finally, existing research on pricing power has mostly been carried out from the perspective of enterprise price strategy (Wildenbeest 2011) and non-price strategy game (Hafezalkotob et al., 2018), with less attention paid to the role of customer choice. This study takes customer perception as an intermediary variable because customers' willingness to pay a premium plays a key role in the formation of pricing power.

\section{Managerial implications}

The conclusions above offer the following implications for online retailers. The first implication is that non-price factors are also capable of forming competitive advantages for online retailers. They can compete through differentiation, not just through price competition. A fundamental way for online retailers to sustain their development is to attract more customers and accordingly gain higher revenues through differentiation competition.

Second, the results indicate that online retailers can improve their market competitiveness by increasing their differentiation, especially the quality of commodities and logistics, which provides a new direction for the formulation of online retailers' marketing strategies. Improving commodity and logistics quality has evolved as the 
primary direction for the future development of online retailers, especially due to the fact that current online shopping demand from customers increasingly emphasizes quality and service. Improving the quality of goods is essential to attract customers to re-purchase and build customer loyalty. We can infer that it is difficult to achieve long-term development by selling fake and inferior commodities. Diversification of commodity categories will help to increase customer loyalty and consequently build pricing power. Online retailers can enlarge their scale of commodity categories by presenting themselves as retail platforms to expand the quantity of stores. Improving the security of online transactions, paying attention to protecting customers' personal information, and transaction information privacy can effectively attract customers' patronage and improve customers' willingness to pay.

Finally, the online retail business can influence customer information by advertising, although it is in fact an exogenous variable. Extensive advertising can intensify customers' perceptions of differentiating features of online retailers, and also raise up barriers to entry against potential competitors, which prolongs the duration of pricing power.

\section{Limitations and further research}

Despite the contributions of this study, there still remain some limitations. First, the descriptions of the differentiated characteristics of online retailers in this study are drawn from the functional perspective of mainstream e-commerce, such as Tmall.com and Jingdong.com, and not all the features of online retailers are listed. At present, the e-commerce industry is in a period of rapid expansion, and the differentiation characteristics of online retailers are being gradually refined. Future research can further refine the differentiation characteristics of online retailers, and even study the pricing power caused by certain functional differences.

Second, this study does not take into account the differences between online retailers' costs. For retail enterprises, the procurement price of a commodity has an important influence on pricing strategies, especially in the case of differences in pricing power. Future research can take into account both the cost advantage and differentiation characteristics of online retailers, so as to conduct in-depth research on pricing from the perspective of the profit space.

Finally, the questionnaire was completed by the same respondents. Although we have adjusted the order of measurement variables, enlarged the composition of respondents and made the deviation acceptable, the deviation still exists. To eliminate common method deviation completely, the price difference of homogeneous commodities in different online retail platforms can be introduced in the future, and verify the hypothesis through experiments or field investigations.

\section{Endnotes}

${ }^{1}$ Lena index: $\mathrm{L}=\frac{\mathrm{P}-\mathrm{MC}}{\mathrm{P}}$. $P$ refers to the enterprise pricing, $M C$ is the industry marginal cost.

Acknowledgements

We would like to extend our heartfelt thanks to the journal's reviewers for their constructive assistance.

Funding

No funding source is available. 
Availability of data and materials

The dataset supporting the conclusions of this article is available upon request.

\section{Authors' contributions}

ZJW and CLZ conceived the study, participated in the design of the research, collected data, performed the statistical analysis, drafted and revised the manuscript. SWT participated in the research design, and helped to draft and revise the manuscript. PL participated in the research design, and helped to revise the manuscript. All authors read and approved the final manuscript.

\section{Competing interests}

The authors declare that they have no competing interests.

The authors confirm that the content of the manuscript has not been published, or submitted for publication elsewhere.

\section{Publisher's Note}

Springer Nature remains neutral with regard to jurisdictional claims in published maps and institutional affiliations.

Received: 7 August 2018 Accepted: 17 January 2019

Published online: 08 February 2019

\section{References}

Ayadi, N., Giraud, M., \& Gonzalez, C. (2013). An investigation of consumers' self-control mechanisms when confronted with repeated purchase temptations: Evidence from online private sales. Journal of Retailing and Consumer Services, 20(3), $272-281$.

Bagozzi, R. P., \& Yi, Y. (1988). On the evaluation of structural equation models. Academy of Marketing Science, 16(1), 74-94.

Bakos, J. Y. (1997). Reducing buyer search costs: Implications for electronic marketplaces. Management Science, 43(12), 1676-1692.

Bendoly, E., Blocher, J. D., Bretthauer, K. M., et al. (2005). Online/in-store integration and customer retention. Journal of Service Research, 7(4), 313-327.

Berenson, R. A., Ginsburg, P. B., Christianson, J. B., et al. (2012). The growing power of some providers to win steep payment increases from insurers suggests policy remedies may be needed. Health Affairs, 31(31), 973-981.

Bhatnagar, A., \& Syam, S. S. (2014). Allocating a hybrid retailer's assortment across retail stores: Bricks-and-mortar vs online. Business Research, 67(6), 1293-1302.

Brody, R. P., \& Cunningham, S. M. (1968). Personality variables and the consumer decision process. Journal of Marketing Research, 50-57.

Caceres, R. C., \& Paparoidamis, N. G. (2007). Service quality, relationship satisfaction, trust, commitment and business-tobusiness loyalty. Nicholas Paparoidamis, 41(7/8), 836-867.

Carlson, J. A., \& McAfee, R. P. (1983). Discrete equilibrium price dispersion. Journal of Political Economy, 91, 480-493.

Čater, T., \& Čater, B. (2010). Product and relationship quality influence on customer commitment and loyalty in b2b manufacturing relationships. Industrial Marketing Management, 39(8), 1321-1333.

Champion, C. J., Hunt, B. J., \& Hunt, G. B. (2010). The effect of retail store image on student perceptions of merchandise quality and willingness to buy. American Journal of Business Research, 3(1), 17-32.

Chen, X., Huang, Q., \& Davison, R. M. (2017a). The role of website quality and social capital in building buyers' loyalty. International Journal of Information Management, 37, 1563-1574.

Chen, Y., Jeon, Y. J., \& Kim, Y. M. (2014). A day without a search engine: An experimental study of online and offline searches. Experimental Economics, 17(4), 512-536.

Chen, Y. J., Hu, X. T., \& Li, S. X. (2017b). Quality differentiation and firms' choices between online and physical markets. International Journal of Industrial Organization, 52(2017), 96-132

Christodoulides, G., \& Michaelidou, N. (2010). Shopping motives as antecedents of e-satisfaction and eloyalty. Journal of Marketing Management, 27(1-2), 181-197.

Christodoulides, G., \& Michaelidou, N. (2011). Shopping motives as antecedents of e-satisfaction and e-loyalty. Journal of Marketing Management, 27(1-2), 181-197.

Davari, A., lyer, P., \& Rokonuzzaman, M. (2016). Identifying the determinants of online retail patronage: A perceived-risk perspective. Journal of Retailing and Consumer Services, 33, 186-193.

Dellaert, B. G., Arentze, T. A., Bierlaire, M., Borgers, A. W., \& Timmermans, H. J. (1998). Investigating consumers' tendency to combine multiple shopping purposes and destinations. Journal of Marketing Research, 177-188.

Dhar, S. K., Hoch, S. J., \& Kumar, N. (2001). Effective category management depends on the role of the category. Journal of Retailing, 77(2), 165-184.

Forsythe, S. M., \& Shi, B. (2005). Consumer patronage and risk perceptions in internet shopping. Journal of Business Research $36(11), 867-875$

Gallino, S., \& Moreno, A. (2012). Integration of online and offline channels in retail: The impact of sharing reliable inventory availability information. Management Science, 60(6), 1434-1451.

Ganesh, J., Reynolds, K. E., Luckett, M., \& Pomirleanu, N. (2010). Online shopper motivations, and e-store attributes: An examination of online patronage behavior and shopper typologies. Journal of Retailing, 86(1), 106-115.

Garvin, D.A. (1987). Competing on the eight dimensions of quality. Harvard Business Review, November-December, 101-109.

Graciola, A. P., Toni, D. D., Lima, V. Z., \& Milan, G. S. (2018). Does price sensitivity and price level influence store price image and repurchase intention in retail markets. Journal of Retailing and Consumer Services, 44(2018), 201-213.

Hafezalkotob, A., Mahmoudi, R., Hajisami, E., et al. (2018). Wholesale-retail pricing strategies under market risk and uncertain demand in supply chain using evolutionary game theory. Kybernetes, 2018(1).

Harris, L. C., \& Goode, M. M. (2004). The four levels of loyalty and the pivotal role of trust: A study of online service dynamics. Journal of Retailing, 80, 139-158. 
Herhausen, D., Binder, J., Schoegel, M., et al. (2015). Integrating bricks with clicks: Retailer-level and channel-level outcomes of online-offline channel integration. Journal of Retailing, 91(2), 309-325.

Hong, I. B., \& Cha, S. (2013). The mediating role of consumer trust in an online merchant in predicting purchase intention. International Journal of Information Management, 33(6), 927-939.

Huang, C. Y. (2011). Excess loyalty in online retailing. International Journal of Electronic Commerce, 16(2), 115-133.

Huang, Y. K., Kuo, Y. W., \& Xu, S. W. (2009). Applying importance-performance analysis to evaluate logistics service quality for online shopping among retailing delivery. International Journal of Electronic Business Management, 7(2), 128-136.

Husain, S. (2017). The determinants of loyalty in online commerce-An exploratory study in India. Electronic Journal of Information Systems in Developing Countries, 81(7), 1-17.

Intyaswati, D., and Komunikasi-Upn, P. (2017). The role of consumer privacy and security on brand loyalty. The International Conference on Corporate and Marketing Communication.

Jain, A. K., Pinson, C., \& Malhotra, N. (1987). Customer loyalty as a construct in the marketing of banking services. The International Journal of Bank Marketing, 5, 49-72.

Jang, H. M., Marlow, P. B., \& Mitroussi, K. (2013). The effect of logistics service quality on customer loyalty through relationship quality in the container shipping context. Transportation Journal, 52(4), 493-521.

Jarmon, R. (2009). Reputation's effect on pricing power: The importance of strategy. Corporate Reputation Review, 12(3), 281-296.

Kirmani, A., \& Rao, A. R. (2000). No pain, no gain: A critical review of the literature on signaling unobservable quality. Journal of Marketing, 64(2), 66-79.

Knop, K., Öncü, J. S., Penzel, J., et al. (2016). Offline time is quality time: Comparing within-group self-disclosure in mobile messaging applications and face-to-face interactions. Computers in Human Behavior, 55(PB), 1076-1084.

Kolesar, M. B., \& Galbraith, R. W. (2000). A services-marketing perspective on e-retailing: Implications for e-retailers and directions for further research. Internet Research, 10(5), 424-438.

Konuk, F. A. (2018). The role of store image, perceived quality, trust and perceived value in predicting consumers' purchase intentions towards organic private label food. Journal of Retailing and Consumer Services, 43, 304-310.

Kotler, P., \& Armstrong, G. (2010). Principle of marketing (13th ed.). New Jersey: Prentice Hall.

Kukar-Kinney, M., \& Close, A. G. (2010). The determinants of consumers' online shopping cart abandonment. Academic Marketing Science, 38(2), 240-250.

Lau, R. S., \& Cheung, G. W. (2012). Estimating and comparing specific mediation effects in complex latent variable models. Organizational Research Methods, 15(1), 3-16.

Lee, H. H., \& Kim, J. (2010). Investigating dimensionality of multichannel retailer's cross-channel integration practices and effectiveness: Shopping orientation and loyalty intention. Journal of Marketing Channels, 17(4), 281-312.

Lewis, B. R., \& Soureli, M. (2006). The antecedents of consumer loyalty in retail banking. Journal of Consumer Behaviour, 5(1), 15-31.

Li, T., Sethi, S. P., \& Zhang, J. (2013). How does pricing power affect a firm's sourcing decisions from unreliable suppliers? International Journal of Production Research, 51(23-24), 6990-7005.

Li, Y. (2014). A multi-level model of individual information privacy beliefs. Electronic Commerce Research and Applications, 13(1), 32-44.

Lin, G. T. R., \& Sun, C. (2009). Factors influencing satisfaction and loyalty in online shopping: An integrated model. Online Information Review, 33(3), 458-475.

Liu, C., \& Arnett, K. P. (2000). Exploring the factors associated with web site success in the context of electronic commerce. Information and Management, 38(1), 23-33.

Luo, J., Ba, S., \& Zhang, H. (2012). The effectiveness of online shopping characteristics and well-designed websites on satisfaction. MIS Quarterly, 36(4), 1131-1144.

Mackinnon, D. P. (2011). Integrating mediators and moderators in research design. Research on social work practice, 21(6), 675-681. Madu, C. N., \& Madu, A. A. (2002). Dimensions of e-quality. International Journal of Quality and Reliability Management, 19(3), 246-258.

Mailath, G. J., \& Samuelson, L. (2014). Repeated games and reputations. Ssrn Electronic Journal, 165-238.

Maltz, A., \& Maltz, E. (1998). Customer service in the distributor channel empirical findings. Journal of Business Logistics, 19(2), 103-130.

Mentzer, J. T., \& Flint, J. (2001). Logistics service quality as a segment-customized process. Journal of Marketing, 65(4), 82-104.

Ngo, V. M., \& Pavelková, D. (2017). Moderating and mediating effects of switching costs on the relationship between service value, customer satisfaction and customer loyalty: Investigation of retail banking in Vietnam. Journal of International Studies, 10(1), 9-33.

Novack, R. A., Rinehart, M., \& Langley, J. (1994). An internal assessment of logistics value. Journal of Business Logistics, 15(1): iviii), 1-128.

Oliver, R. L. (1997). Satisfaction: A behavioral perspective on the consumer. Asia Pacific Journal of Management, 2(2), 285-286.

Pan, Y., \& Zinkhan, G. M. (2006). Determinants of retail patronage: A meta-analytical perspective. Journal of Retailing, 82(3), 229-243.

Park, C., \& Kim, Y. (2003). Identifying key factors affecting consumer purchase behavior in an online shopping context. International Journal of Retail and Distribution Management, 31(1), 16-29.

Pattanayak, D., Koilakuntla, M., \& Punyatoya, P. (2017). Investigating the influence of TQM, service quality and market orientation on customer satisfaction and loyalty in the Indian banking sector. International Journal of Quality and Reliability Management, 34(3), 362-377.

Peštek, A., Resić, E., \& Nožica, M. (2011). Model of trust in e-transactions. Economic Research-Ekonomska Istraživanja, 24(3), 131-146.

Podsakoff, P. M., MacKenzie, S. B., Lee, J. Y., \& Podsakoff, N. P. (2003). Common method biases in behavioral research: A critical review of the literature and recommended remedies. Journal of Applied Psychology, 88(5), 879-903.

Raju, J. S., Srinivasan, V., \& Lal, R. (1990). The effects of brand loyalty on competitive price promotional strategies. Management Science, 36(3), 276-304.

Reich, A. Z., McCleary, K. W., Tepanon, Y., et al. (2006). The impact of product and service quality on brand loyalty. Journal of Foodservice Business Research, 8(3), 35-53.

Reichheld, F. F., \& Sasser, W. (1990). Zero defections: Quality comes to services. Harvard Business Review, 68(5), 105-111.

Ribbink, D., Riel, A. C. R. V., Liljander, V., \& Streukens, S. (2004). Comfort your online customer: Quality, trust and loyalty on the internet. Journal of Service Theory and Practice, 14(6), 446-456.

Richards, T. J., \& Pofahl, G. (2010). Pricing power by supermarket retailers: A ghost in the machine? Choices the Magazine of Food Farm and Resource Issues, 25(2). 
Robinson, J. (2011). Hospitals respond to medicare payment shortfalls by both shifting costs and cutting them, based on market concentration. Health Affairs, 30(7), 1265-1271.

Rohm, A. J., \& Swaminathan, V. (2004). A typology of online shoppers based on shopping motivations. Journal of Business Research, 57(7), 748-757.

Sarv, D., Khalil, F. M., \& Edward, C. (2001). Product and service quality: The antecedents of customer loyalty in the automotive industry. Production and Operations Management, 10(4), 424-439.

Shankar, V., Smith, A. K., \& Rangaswamy, A. (2003). Customer satisfaction and loyalty in online and offline environments. International Journal of Research in Marketing, 20(2), 153-175.

Shapiro, C. (1983). Premiums for high quality products as returns to reputations. The Quarterly Journal of Economics, 98(4), 659-679.

Srinivasan, S. S., Anderson, R., \& Ponnavolu, K. (2002). Customer loyalty in e-commerce: An exploration of its antecedents and consequences. Journal of Retailing, 78(1), 41-50.

Steinfield, C., Bouwman, H., \& Adelaar, T. (2002). The dynamics of click-and-mortar electronic commerce: Opportunities and management strategies. International Journal of Electronic Commerce, 7(1), 93-119.

Szymanski, D. M., \& Hise, R. T. (2000). E-satisfaction: An initial examination. Journal of Retailing, 76(3), 309-322.

Vogt, W. B., Town, R., \& Williams, C. H. (2006). How has hospital consolidation affected the price and quality of hospital care? Synthesis Project Research Synthesis Report, 2006(9).

Wachyudi, N. (2017). The role of satisfaction in mediating the effect of product quality, service quality and price fairness on the consumer loyalty of online store. European Journal of Business and Management, 9(35), 13-20.

Waldman, D. E., and Jensen, E. J. (2013) Industrial organization: Theory and practice. Pearson Education, 2013.

Wangenheim, F., \& Bayon, T. (2004). Satisfaction, loyalty and word of mouth within the customer base of a utility provider: Differences between stayers, switchers and referral switchers. Journal of Consumer Behaviour, 3(3), 211-220.

Whitefield, R. I., \& Duffy, A. H. B. (2012). Extended revenue forecasting within a service industry. International Journal of Production Economics, 141(2), 505-518.

Wildenbeest, M. R. (2011). An empirical model of search with vertically differentiated products. The Rand Journal of Economics, 42, 729-757.

Wimble, M., Tripp, J., Phillips, B., et al. (2016). On search cost and the long tail: The moderating role of search cost. Information Systems and e-Business Management, 14(3), 1-25.

Yuen, E. F. T., \& Chan, S. S. L. (2010). The effect of retail service quality and product quality on customer loyalty. Journal of Database Marketing and Customer Strategy Management, 17(3-4), 222-240.

Yun, K. C. (2015). Creating customer repurchase intention in internet retailing: The effects of multiple service events and product type. Journal of Retailing and Consumer Services, 22, 213-222.

Zehir, C., \& Narcıkara, E. (2016). E-service quality and e-recovery service quality: Effects on value perceptions and loyalty intentions. Procedia-Social and Behavioral Sciences, 229, 427-443.

Zeithaml, V. A., Berry, L. L., \& Parasuraman, A. (1996). The behavioral consequences of service quality. Journal of Marketing, 60(4), 31-46.

Zhang, J., Farris, W., \& Irvin, W. (2010). Crafting integrated multichannel retailing strategies. Journal of Interactive Marketing, 24(2), 168-180.

Zhelobodko, E., Kokovin, S., Parenti, M., \& Thisse, J. F. (2012). Monopolistic competition: Beyond the constant elasticity of substitution. Econometrica, 80(6), 2765-2784.

Zhuang, H., Leszczyc, P. T. L. P., \& Lin, Y. (2018). Why is price dispersion higher online than offline? The impact of retailer type and shopping risk on price dispersion. Journal of Retailing, 94(2), 136-153.

\section{Submit your manuscript to a SpringerOpen ${ }^{\circ}$ journal and benefit from:}

- Convenient online submission

- Rigorous peer review

- Open access: articles freely available online

- High visibility within the field

- Retaining the copyright to your article

Submit your next manuscript at $\boldsymbol{\nabla}$ springeropen.com 